\title{
Correction to: Stability, variation, and application of AFIS fiber length distributions
}

HINDS Zachary ${ }^{1}$, KELLY Brendan Robert ${ }^{1,2^{*}}$ and HEQUET Eric Francois ${ }^{1}$

\section{Correction to: J Cotton Res (2020) 3:10 \\ https://doi.org/10.1186/s42397-020-00053-5}

In the original publication of this article (HINDS et al. 2020) the Table 7 is not correct, the correct table is as below. The error in this Correction has been updated in the original article.

Published online: 12 June 2020

Table 7 Eigenvalues and explanation percentages of three components of PCA on three different populations

\begin{tabular}{|c|c|c|c|c|c|c|}
\hline & \multicolumn{2}{|l|}{ PC1 } & \multicolumn{2}{|l|}{ PC2 } & \multicolumn{2}{|l|}{ PC3 } \\
\hline & Eigen & $\begin{array}{l}\text { Percent } \\
\text { Explained }\end{array}$ & Eigen & $\begin{array}{l}\text { Percent } \\
\text { Explained }\end{array}$ & Eigen & $\begin{array}{l}\text { Percent } \\
\text { Explained }\end{array}$ \\
\hline$A B$ & 58.5 & 74.0 & 18.1 & 22.9 & 1.6 & 2.0 \\
\hline EL & 68.3 & 86.5 & 8.4 & 10.7 & 1.1 & 1.4 \\
\hline Gl & 64.6 & 81.8 & 11.7 & 14.8 & 1.3 & 1.7 \\
\hline
\end{tabular}

\section{Reference}

Hinds Z, Kelly BR, Hequet EF. Stability, variation, and application of AFIS fiber

length distributions. J Cotton Res. 2020;3:10. https://doi.org/10.1186/s42397020-00053-5

The original article can be found online at https://doi.org/10.1186/s42397020-00053-5.

* Correspondence: zach.hinds@ttu.edu

${ }^{1}$ Texas Tech University, 2500 Broadway, Lubbock, TX 79409, USA

${ }^{2}$ Texas AgriLife Research, 1102 E Farm to Market Rd 1294, Lubbock, TX 79403, USA

(c) The Author(s). 2020 Open Access This article is licensed under a Creative Commons Attribution 4.0 International License, which permits use, sharing, adaptation, distribution and reproduction in any medium or format, as long as you give appropriate credit to the original author(s) and the source, provide a link to the Creative Commons licence, and indicate if changes were made. The images or other third party material in this article are included in the article's Creative Commons licence, unless indicated otherwise in a credit line to the material. If material is not included in the article's Creative Commons licence and your intended use is not permitted by statutory regulation or exceeds the permitted use, you will need to obtain permission directly from the copyright holder. To view a copy of this licence, visit http://creativecommons.org/licenses/by/4.0/. 